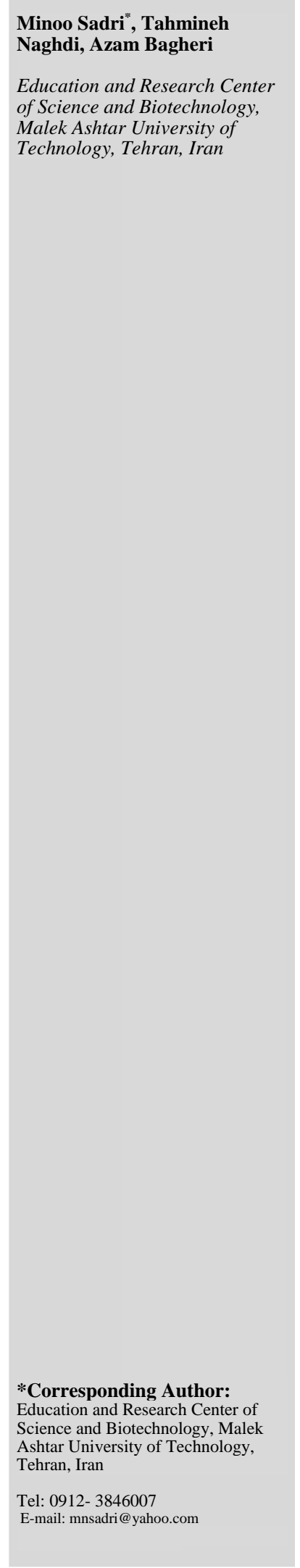

\section{Preparation and Evaluation of Composite Nanofibers Containing Vancomycin}

Received:15 Jul. 2017; Accepted: 4 Jan. 2018

\section{Abstract}

Background: Electrospinning of chitosan/poly ethylene oxide (CS/PEO) and poly caprolactone (PCL)/ CS/ PEO/ solutions with the addition of vancomycin to create nanofibers with antibacterial properties were examined.

Methods: Polymeric nanofibers including CS/PEO and PCL /CS/PEO/ vancomycin were produced by electrospinning method. The morphology of electrospun nanofibers was studied with use of scanning electron microscopy (SEM). Moreover, the chemical structures of the nanofibers were evaluated by FT-IR. The drug release of nanofibers was also investigated by UV-Vis spectrophotometry. The antibacterial activity of scaffolds was tested by two type bacteria including Streptococcus pyogenes and Staphylococcus aureus.

Results: The SEM images indicated that the addition of vancomycin as much as $0 / 8 \% w t$ brings about the best nanofiber. Also, the morphology of electrospun nanofiber is dependent on the viscosity of the solution and the ratio of PCL/CS /PEO/vancomycin. According to the results of vancomycin releasing from nanofibers, the best results were obtained in the presence of $\mathrm{PCL} / \mathrm{CS} / \mathrm{PEO} / 0 / 8 \% \mathrm{wt}$ vancomycin nanofibers as healing sample.

Conclusion: The result of antibacterial activity of nanofiber and drug releasing showed this nanofiber can used as an antibacterial coating to prevent the spread of infections in the wound surface.

Keywords: Chitosan, Poly ethylene oxide, Poly caprolactone, Vancomycin, Nanofiber 


\section{تهيه و بررسى خواص نانو الياف كامبوزيتى حاوى ونكومايسين}

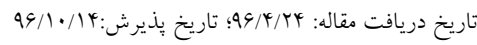

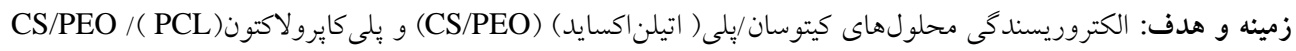

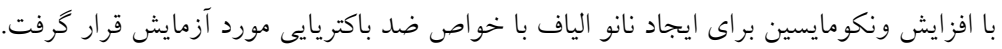

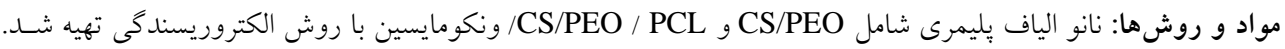

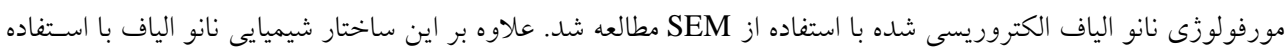

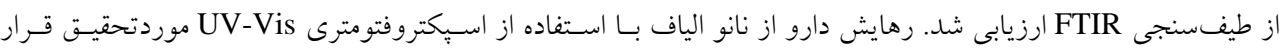

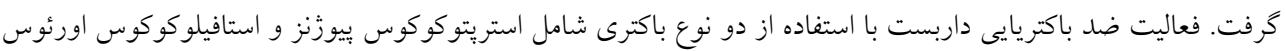
مورد آزمايش قرار خرفت.

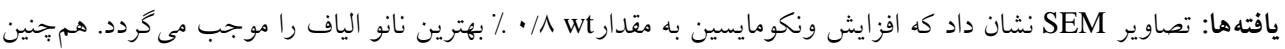

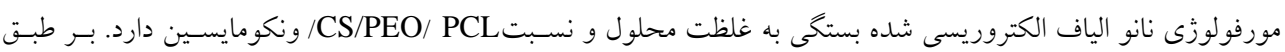

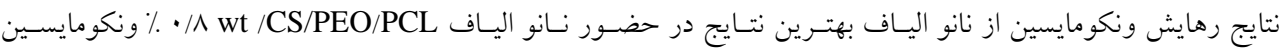

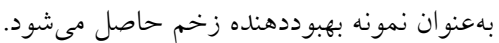

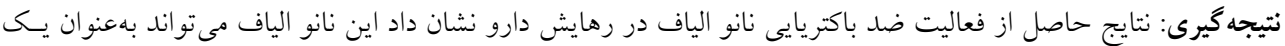
يوشش ضل باكتريايى براى ممانعت از يخش شدن عفونت در سطح زخم استفاده شود. كلمات كليدى: كيتوسان، بِلى (اتيلن اكسايد)، بِلى كايرولاكتون، ونكومايسين، نانو الياف

ماترى صدرى"، تهمينــه نقــدى، اعظــم باقرى يُروهشكده علوم و فناورى زيستى دانشكاه صنعتى مالى /شتر، تهران، /يران

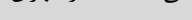


همجينين به علت داشتن ساختار انعطاف بـــير در بهبـود الاستيسيته مقدمه لاستيكها و زيست سازگارى و نرخ زيست تخريب يذيرى بايين، در

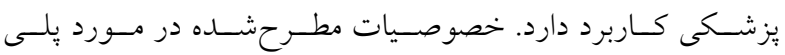
كايرولاكتون مىتواند دلايل خوبى براى استفاده از اين بليمر به عنوان

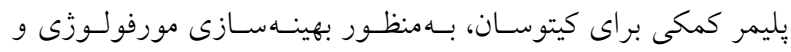

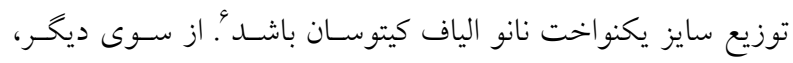

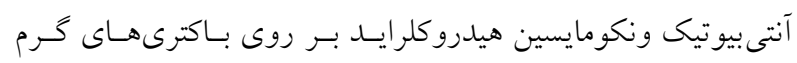

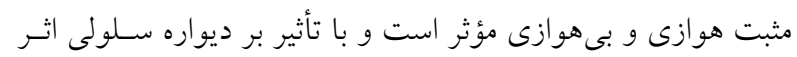
باكتريوسيد بر آنها مى كذارد.

در ايسن تحقيسق سـعى بــراين بـود كـه، بــا اسـتفاده از محلـول

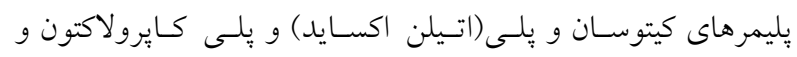

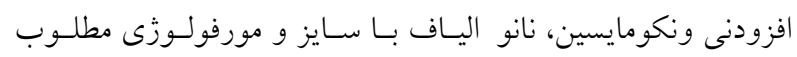
جهـت درمـان عفونستهــاى باكتريـايى تهيـهـ و بــا روش كار آمــد ميكروسكوبٍ الكترونى روبشى بررسى شوند.

\section{مواد و روشها}

مواد: يليمرهاى كيتوسان با وزن مولكولى متوسط ، يُلى (اتسيلن

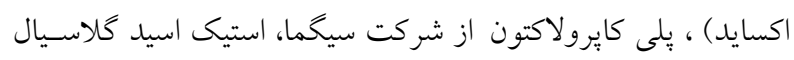

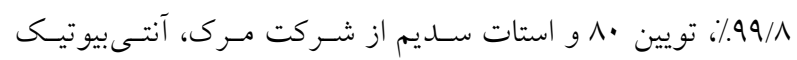

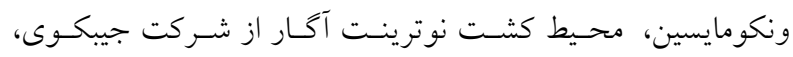
باكترى اسـتافيلوكوكوس اورئسوس (سـويه (ATCC33591)، بـاكترى استريتوكوكوس بيوزنز (سويه PTCC1447).

\section{تهيه محلول بلى كايرولاكتون / كيتوسان/ ونكومايسين} در ابتدا، بهمنظور تهيه محلول كيتوسان- بلى (اتيلن اكسـايد) بـا

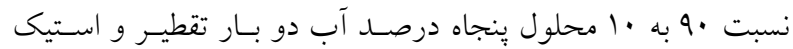

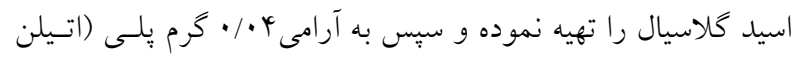

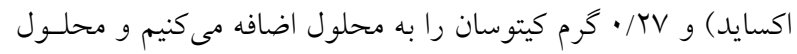
را تا به دست آمدن يك محلول همخًن بر روى استيرر قرار مىدهيم.

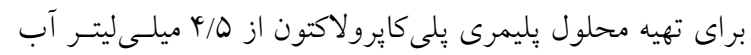

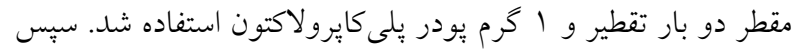

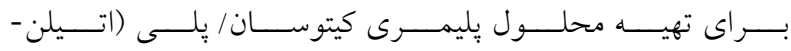

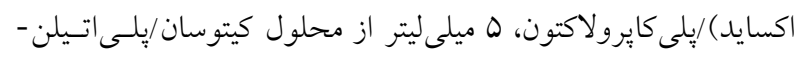

نانو الياف كاربردهاى مختلفى در زمينههاى فيلتراسـيون، تثبيـت

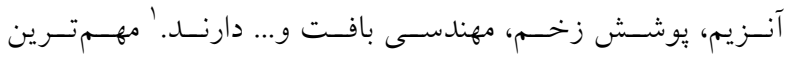
خصوصيات آنها قطر كم، يكنواخت بـودن تخلفــل لايسههـاى نـانو

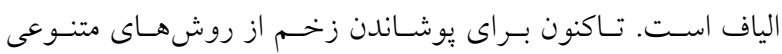

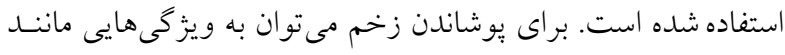

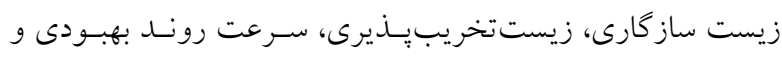
ترميم زخم، جلو گيرى از ايجاد عفونت ثانويه، جلـو گيرى از اسـكار

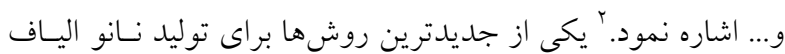

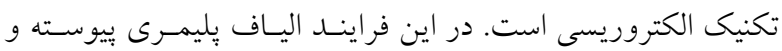

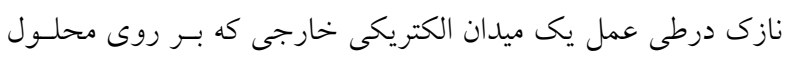

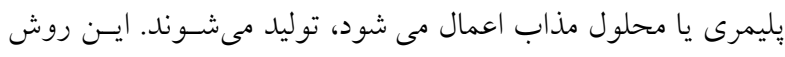

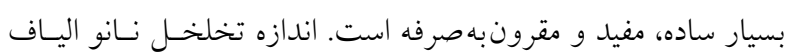
الكتروريسى شده و زيست ساز كارى آنها، اين اليـاف را بـه گزينـهـ مناسبى براى انواع كاربردهاى بزشكى تبديل نموده اسـت. بـ اسـتفاده از نانو الياف مانع مقاومت دارويى در زخم، تعويض مكرر بانسمان، عوارض جانبى داروها و عفونتهاى ثانويه در درمـانهـاى مرسـوم

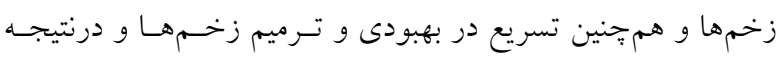
كاهش طول مدت درمان مىشود.' استفاده از يُليمرهايى از قبيل كيتوسان براى دارورسانى به منطقه مناسب در سيستم بيولوزيك جذابيت زيادى را ايجـاد كـرده اسـت.

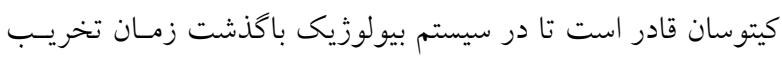

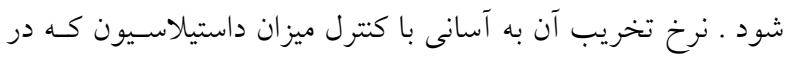
حين فراورى رخ مىدهد ، قابل برنامهريزى اسـت. ايسن موضـوع بـهـ دارو اجازه مى دهد تا به صورت كنترلشده در موضـع مناسـب بـــن

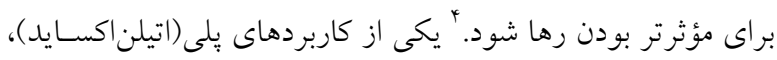

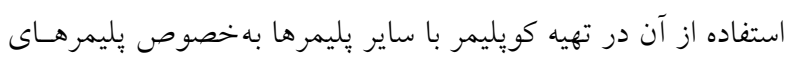

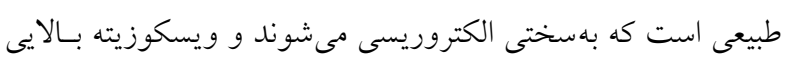

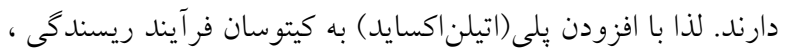
بهتر و راحتتر انجام مى شود.

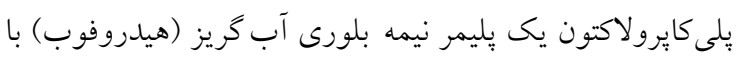
فرمول مولكولى

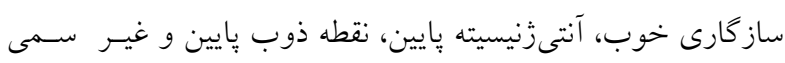

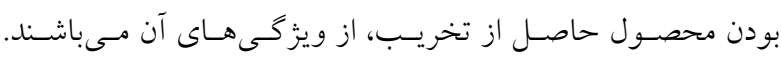


آزادسازى دارو از نانو الياف الكتروريسى شــه Cs/PEO/PCL/Ant، از دستخاه طيفسنج UV-Vis استفاده شد. همه آزمايشها در طولموج جذب ماكسيمم •^^ نانومتر انجام شد.

\section{نتايج و بحث}

يس از تهيه نانو الياف، تصاوير SEM تهيه شد. همانطور كه در

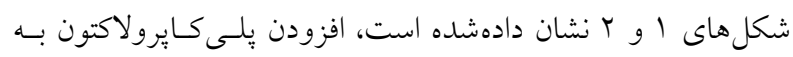

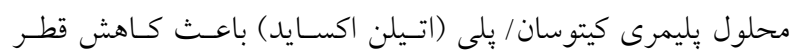

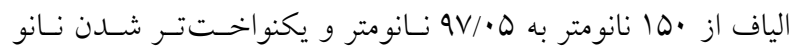
الياف مىشود. در ادامه، با افزودن آنتىبيوتيك ونكومايسـين و تهيـه

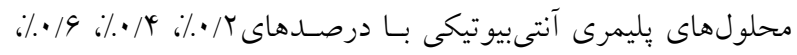

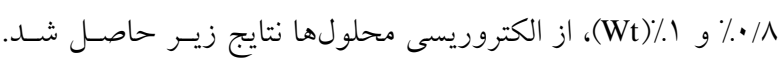

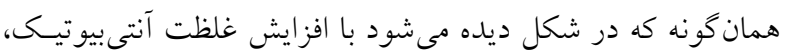
سايز نانو الياف كاهش مىيابد. از سوى ديخر نانو اليـاف كيتوسـان/ يلىاتيلن اكسايد و 1 ٪ وزنى از سيليكا و ه/ • ٪ وزنى از سـفازولين

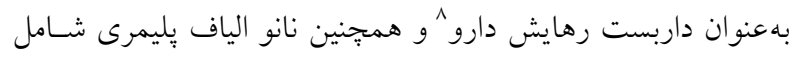

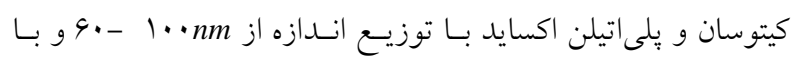

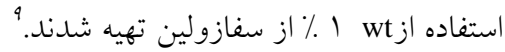
درحالى كه در ايسن كارهمـان كونـه كـه از تصـاوير SEM ديـده مىشود افزودن يلى كايرولاكتون و ونكومايسين به محلول كيتوسـان

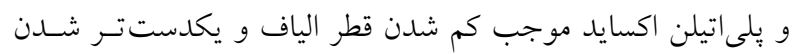

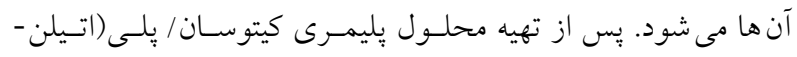

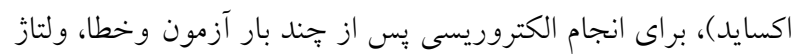
1/ كيلوولت، نرخ تغذيه ه/ • ميلى ليتر بر ساعت و فاصله 9 سـانتى -

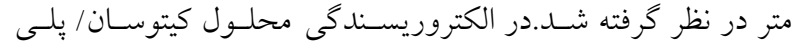

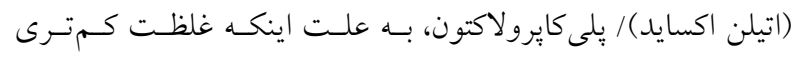
نسـبت بـه محلـول كيتوسـان/يلـى (اتسيلن اكسـايد) داشـت، بــراى جلو گيرى از پاشش نامنظم در اثر كاهش غلظت، نرخ تغذيه و ولتاز كمتر و به ترتيب ץ/ • ميلىليتر بـر سـاعت و ا كيلوولـت در نظـر كرفته شد. با افزودن مقادير مختلف آنتسىبيوتيـك ونكومايسـين بـهـ

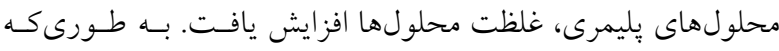
ولتاز IV كيلوولت براى يرتاب جت يليمرى به سمت صفحه جمـع

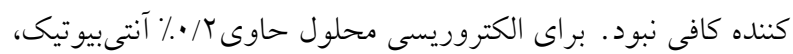

اكسايد با ه ميلىليتر از محلول يلى كايرولاكتـون تركيـبـشــه و بــه

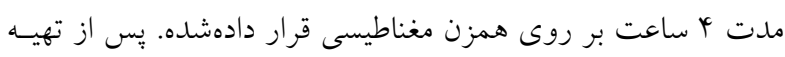

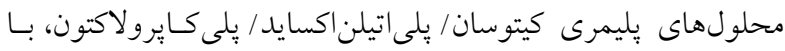

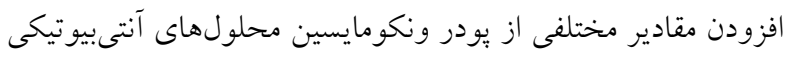

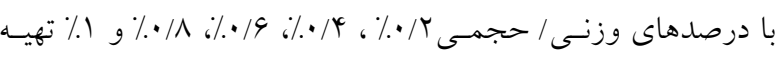

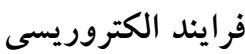

براى انجام الكتروريسى (بـا استفاده از دستـاه الكتروريسىى

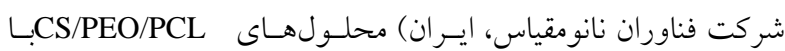
درصدهاى مختلف آنتى بيوتيك ونكومايسين، بهينهسازى سه يـارامتر مهم در فرايند الكتروريسى يعنى ولتـاز، فاصـله بـين نـوك نـازل و صفحه جمع كنناه و نرخ تغذيه صورت گرفت. ولتـاز در محسدوده

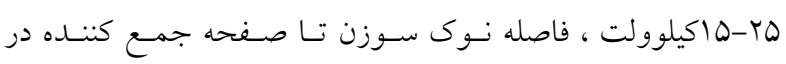

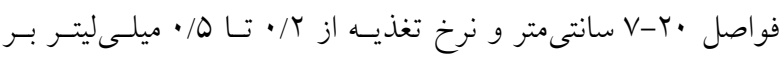
ساعت در نظر كرفته شد. مورفولوزى و قطر نـانو اليـاف حاصـل از فرايند الكتروريسى با اسـتفاده از ميكروسكوبٍ الكترونسى روبشى بررسى شد.

\section{آزمايش باكترىشناسى}

براى تست باكتريايى نانو الياف نهايى از محيط نوترينت آكار و

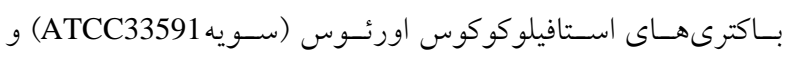
استريتوكوكوس بيوزنز (سويه PTCC1447) استفاده شد.

\section{آناليز طيفنحارى مادونقرمز تبديل فوريه (FTIR)} ويزگ گهاى تركيبى و شيميايى داربست نانو الياف الكتروريسى شده Cs/PEO/PCL حساوى و فاقـــ آنتسى بيوتيـك ونكومايسـين بــا

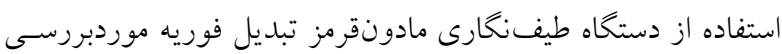

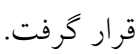

بررسى آزادسازى آنتىبيوتيك از داربست نانو الياف

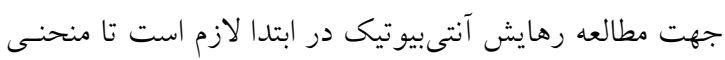

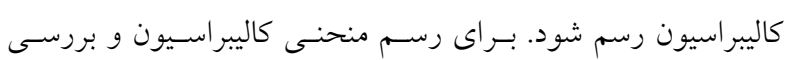


تغذيه باعث مىشود كه تبخير كامل حلال صورت نخيـــ كـه بــراى

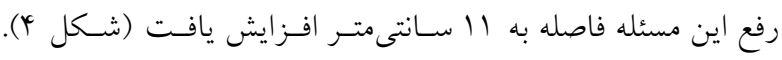

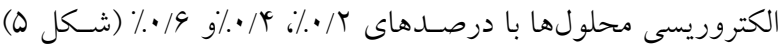

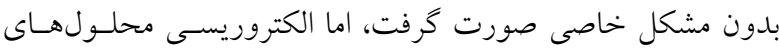

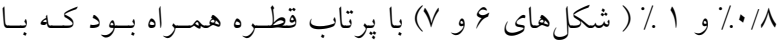
تغييرات جزئى ولتاز، دبى و فاصله ميزان قطرات كمتر شد.
ولتاز 19 كيلوولت در نظر كرفته شد و براى اين كه حلال كاملاً قبـل از رسيدن محلول به صفحه جمع كننده كـاملاً تبخيــر شـود، فاصـله به اندازه • ( سانتى متر تنظيم شد (شكل ץ). براى الكتروريسى محلول حاوى ٪/ • آنتى بيو تيك به علت افزايش غلظت، ميزان ولتاز به اندازه

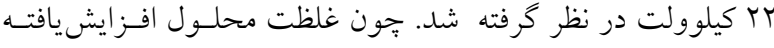

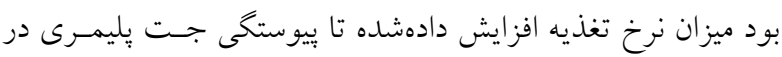
هنخام حركت به سمت صفحه جمع كننده حاصل شود. افزايش نرخ

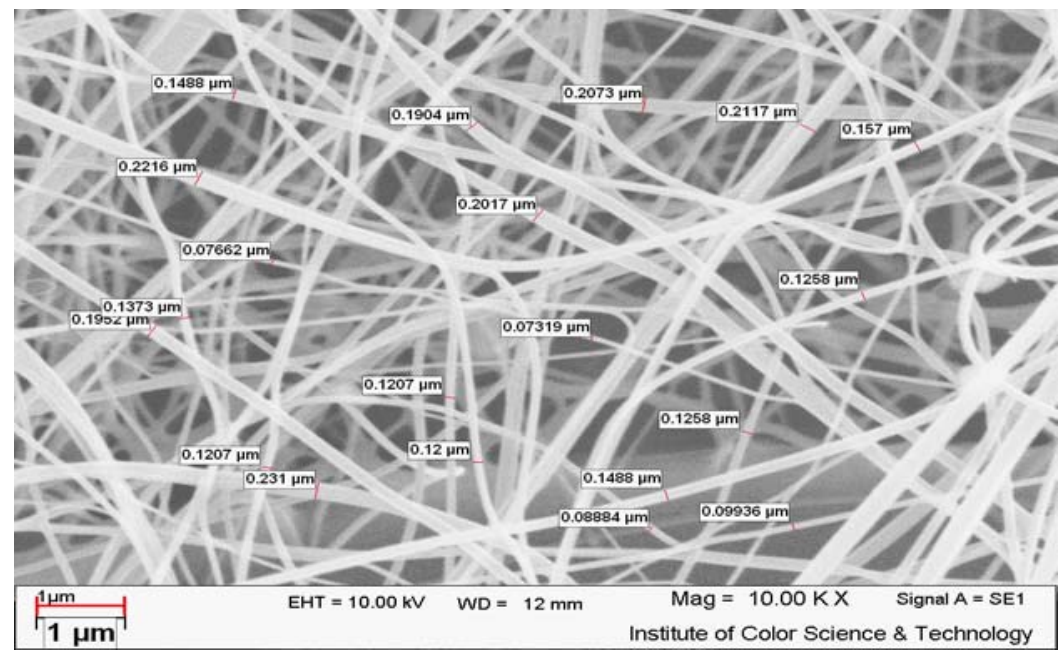

شكل ا: تصوير SEM نانو الياف كيتوسان/ يلى (اتيلناكسايد) با قطر الياف ميانخين •ما نانومتر

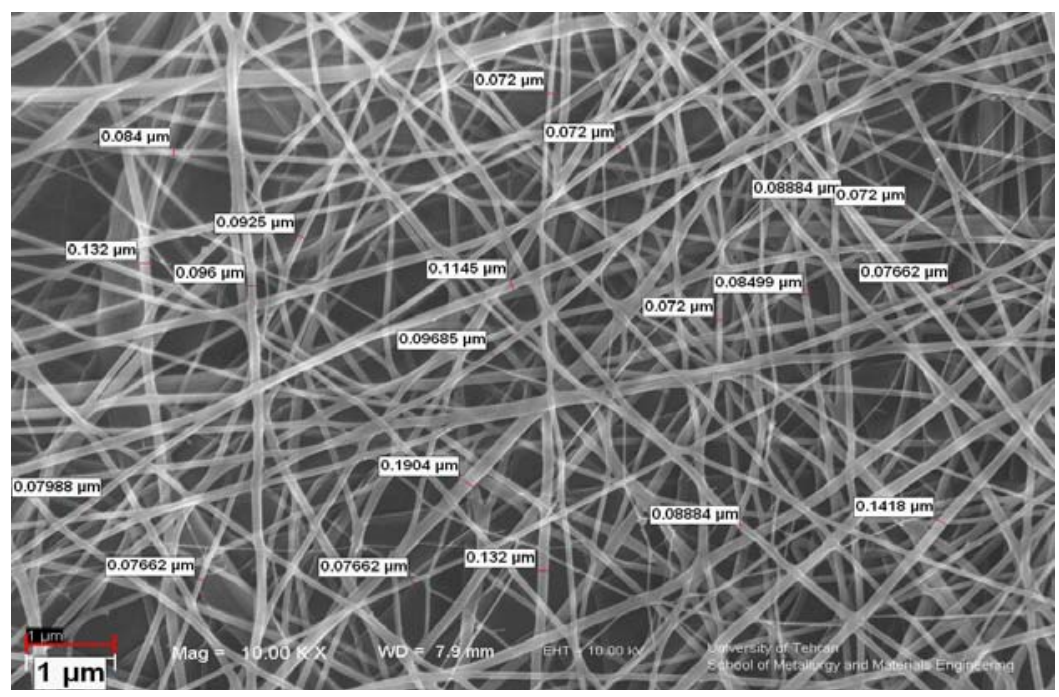

شكل r: تصوير SEM نانو الياف كيتوسان/ بلى (اتيلناكسايد)/ بلى كابرولاكتون با قطر الياف ميانخين 9V نانومتر 

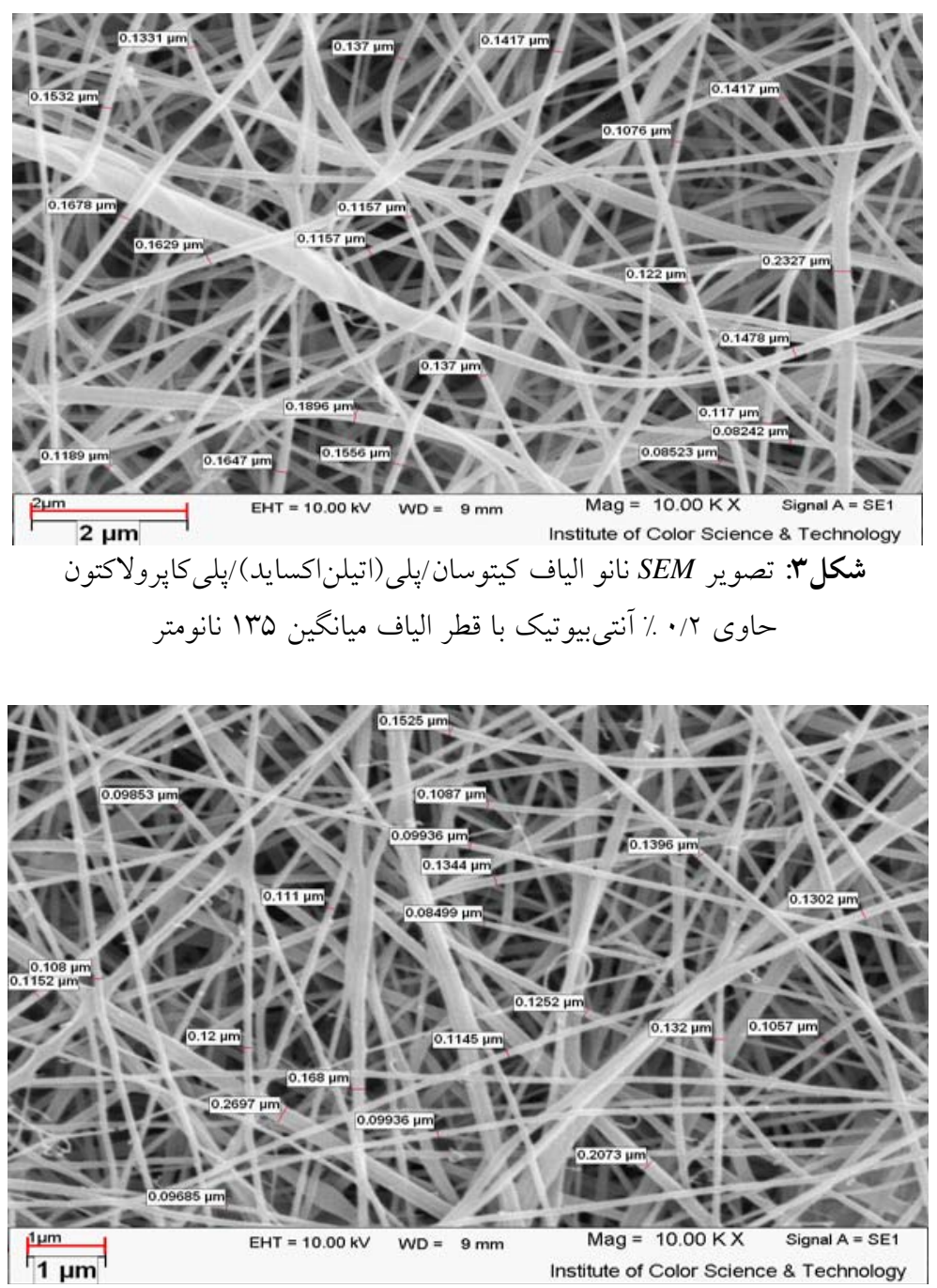

شكل fا: تصوير SEM نانو الياف كيتوسان/يلى(اتيلناكسايد)/يلى كايرولاكتون

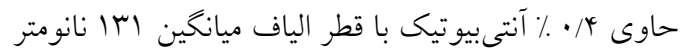

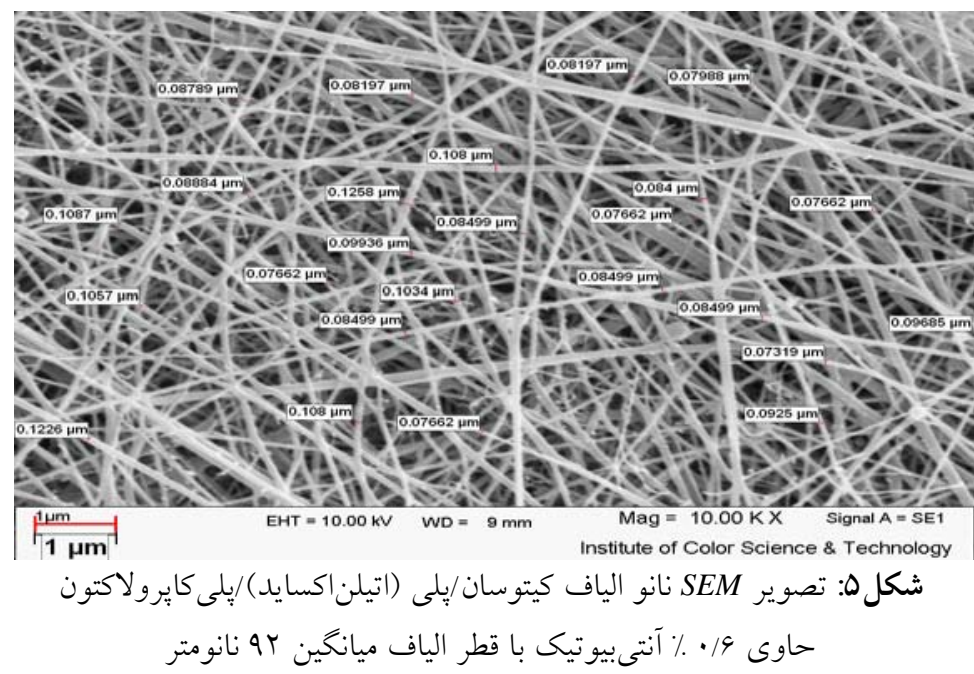



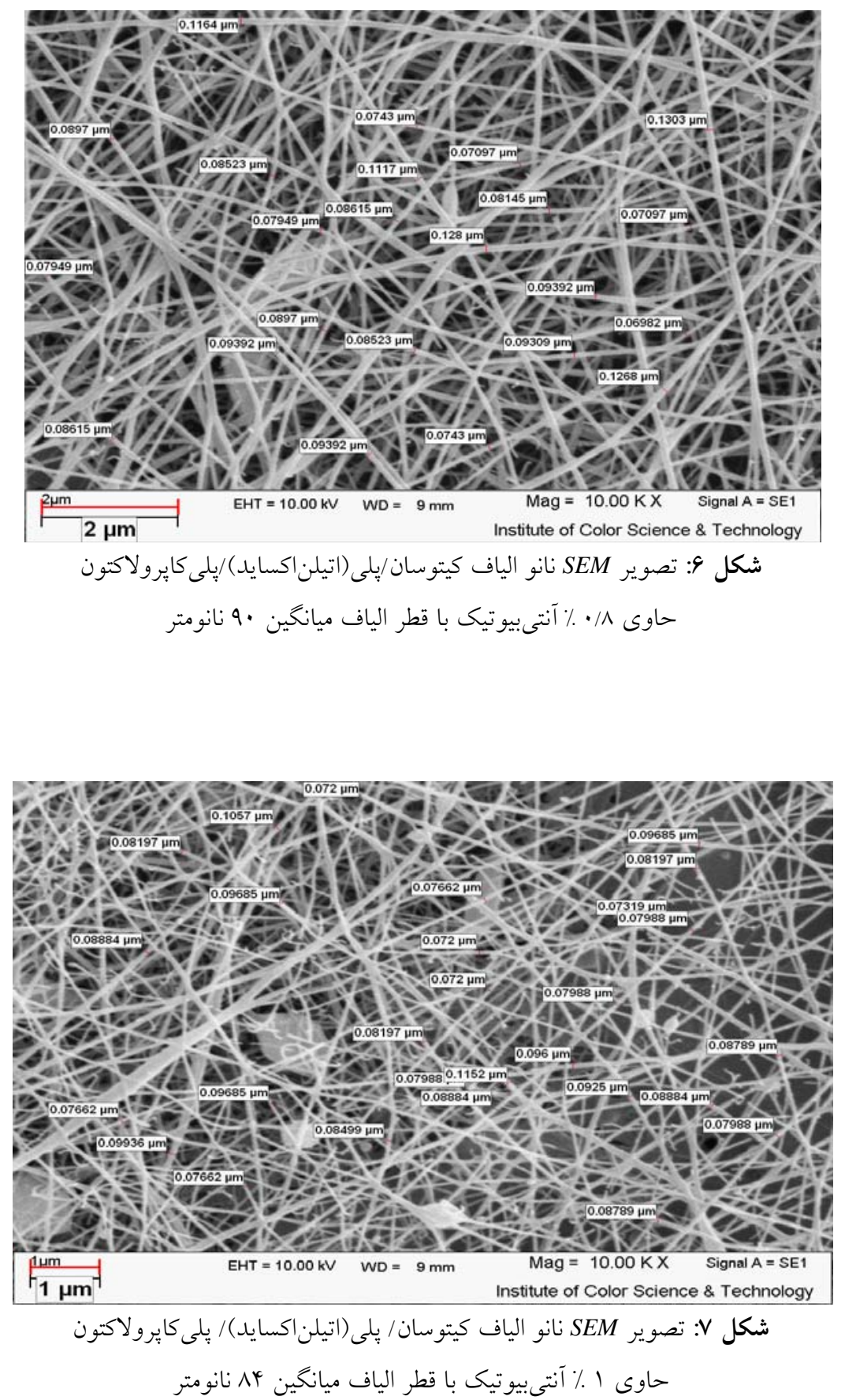

جداول ا و r قطر هاله عـــم رشــ حاصـل از تاثيرنـانو اليـاف بــــ

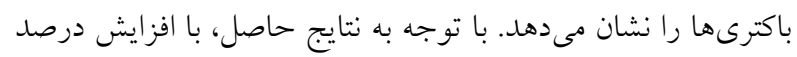

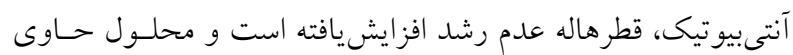
CS/PEO/PCL تنها مىتواند باعث كاهش رشد باكترى شود.

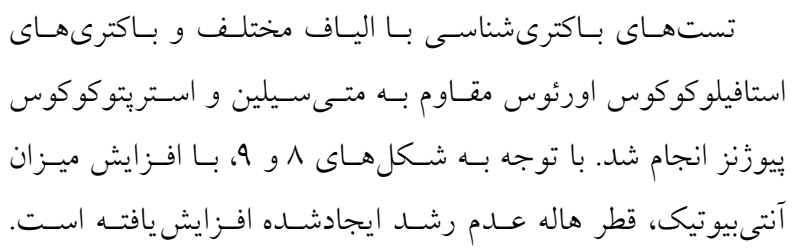




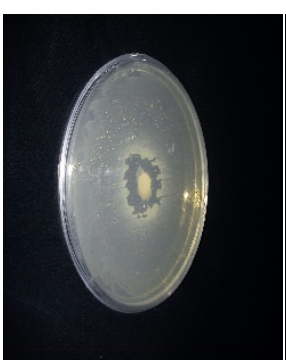

(๑)

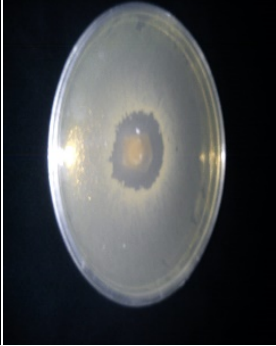

(د)

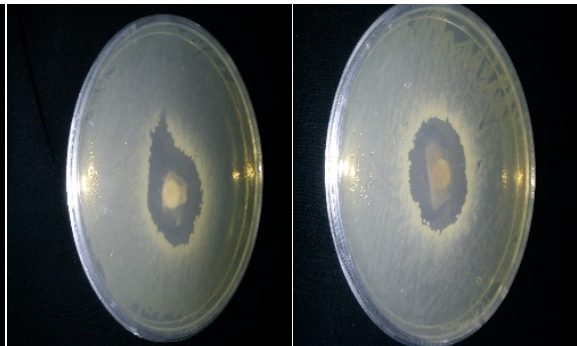

(ج)

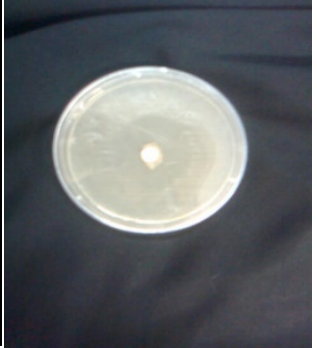

(الف)

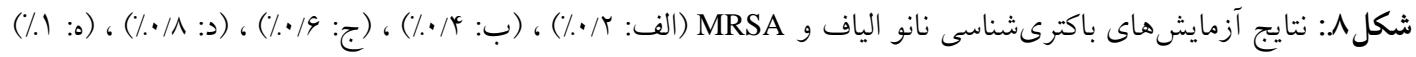

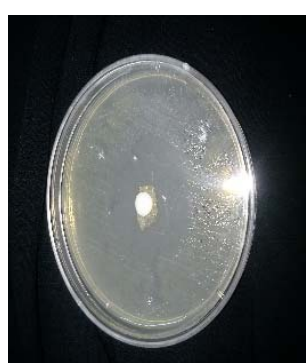

(०)

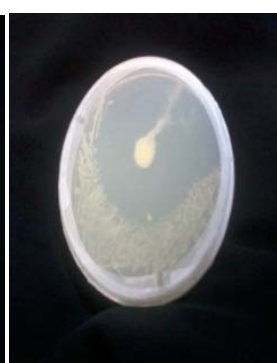

(د)

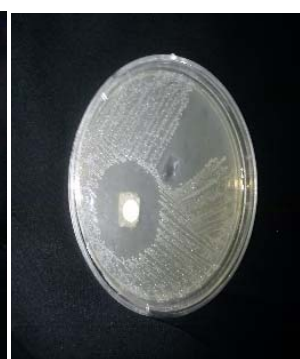

(ج)

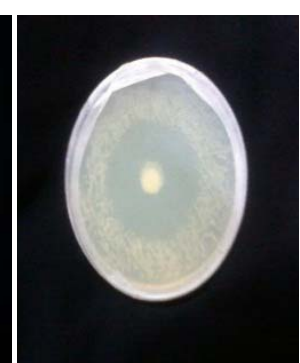

(ب)

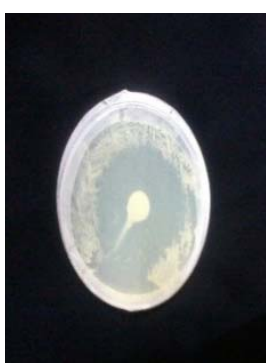

(الف)

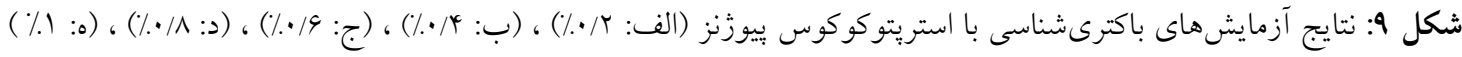

جدول ا: نتايج آزمايشهاى باكترىشناسى با نانو الياف بِيمرى و Methicillin-resistant

(MRSA )Staphylococcus aureus

\begin{tabular}{|c|c|}
\hline قطر هاله عدم رشد(mm) & نانو الياف مورد آزمايش \\
\hline$\checkmark$ & $\% / r$ Cs/PEO/PCL/vanko \\
\hline $1 \cdot$ & $\% \bullet /$ Cs/PEO/PCL/vanko \\
\hline ir & $\% / 9 \mathrm{Cs} / \mathrm{PEO} / \mathrm{PCL} /$ vanko \\
\hline 14 & $\% \cdot / \wedge$ Cs/PEO/PCL/vanko \\
\hline IV & \% Cs/PEO/PCL/vanko \\
\hline
\end{tabular}

\begin{tabular}{|c|c|}
\hline قطر هاله عدم & نانو الياف مورد آزمايش \\
\hline- & Cs/PEO/PCL \\
\hline 11 & $\% \cdot / \mathrm{Cs} / \mathrm{PEO} / \mathrm{PCL} /$ vanko \\
\hline ir & $\% \cdot / \uparrow C s / P E O / P C L /$ vanko \\
\hline$r r$ & $\% \cdot / 9 \mathrm{Cs} / \mathrm{PEO} / \mathrm{PCL} /$ vanko \\
\hline rq & $\% / \wedge \mathrm{Cs} / \mathrm{PEO} / \mathrm{PCL} /$ vanko \\
\hline TV & \% । Cs/PEO/PCL/vanko \\
\hline
\end{tabular}


معنادارى در بيكىهاى كششى بهجز ناحيه

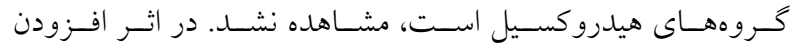
ونكومايسين به علت افزايش گروههاى هيدروكسيل، بهناى اين بيكى

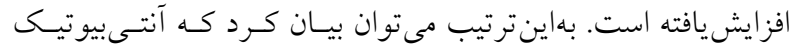

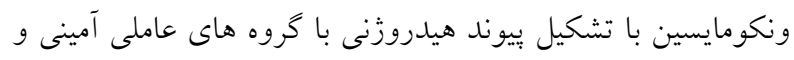

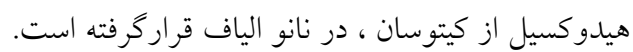

كروههاى عاملى موجود در نانو الياف با استفاده از طيفنخــارى مادون قرمز در محدوده

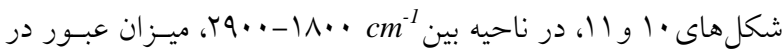

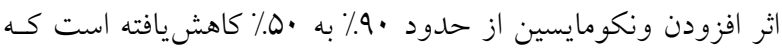

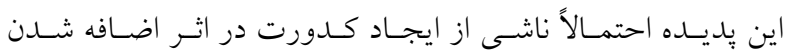
ونكومايسين و افزايش جذب مىباشد. اين در حالى است كه تغييـر

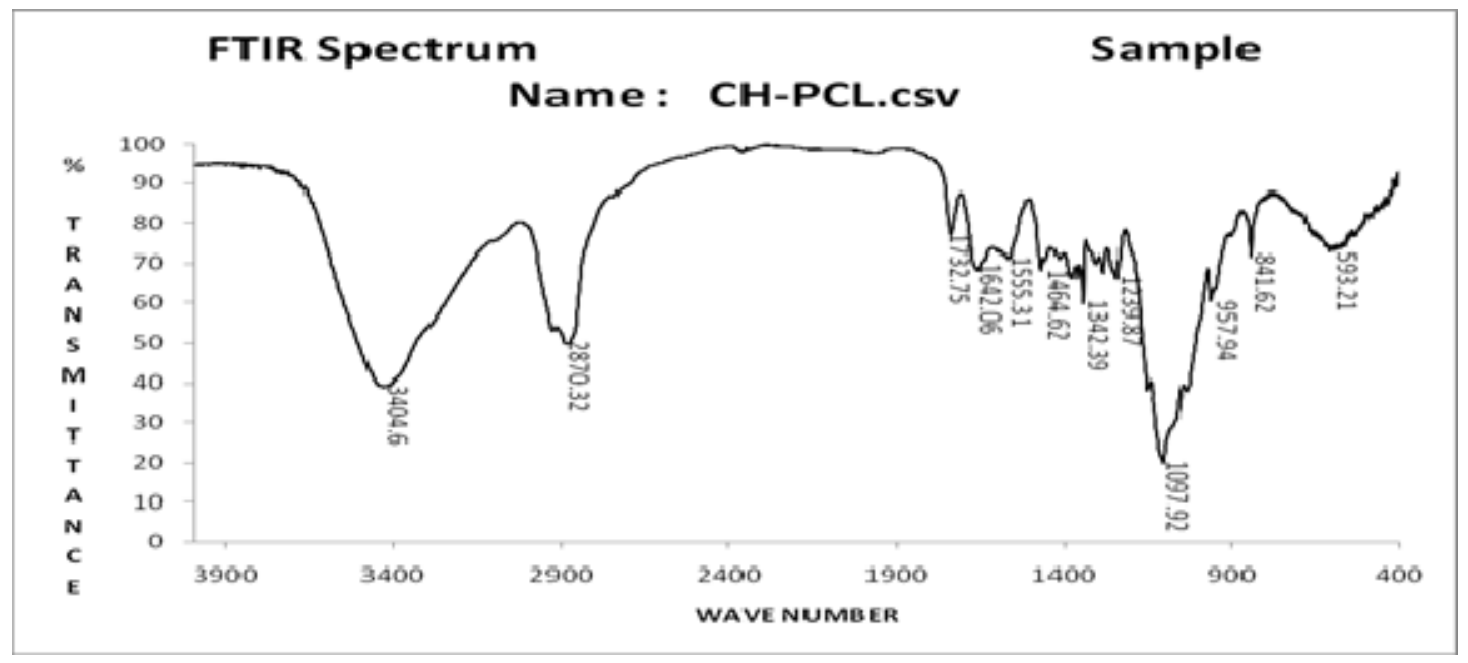

شكل • ا: نمودار Cs/PEO/PCL FTIR فاقد ونكومايسين

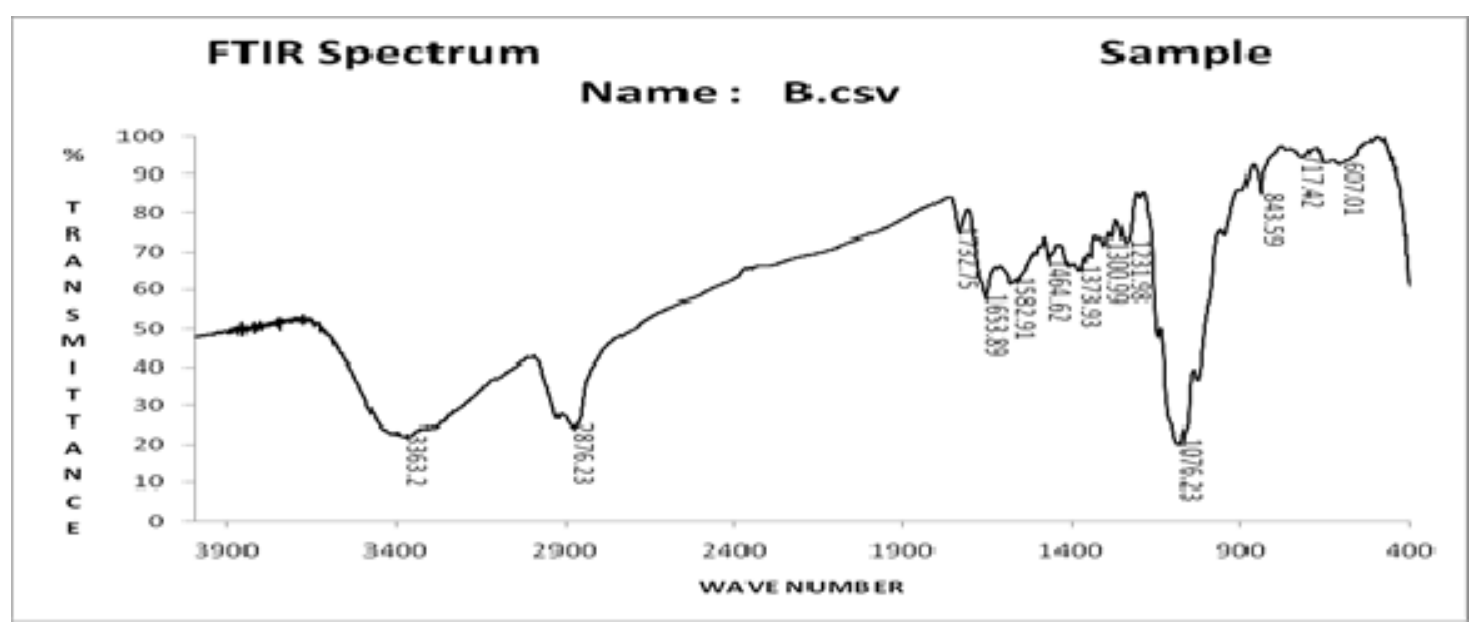

شكل 11: نمودار Cs/PEO/PCL FTIR حاوى ونكومايسين 
است كه در لابهلاى داربست نانو الياف گير افتادهاند. بديده نفـوذ در

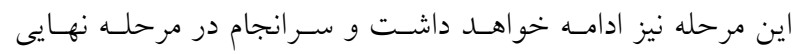
رهايش از غلظت ماده مؤثره كاسته مىشود و سرعت رهايش خيلى

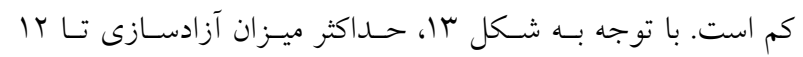

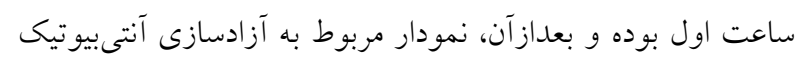
از نانو الياف بهصورت ثابت باقى مى ماند. اين نحوه آزادسازى مسى تواند براى ترميم زخم مناسب باشد.
در شكل r ا منحنى كاليبراسـيون ونكومايسـين نشـان دادهشـده

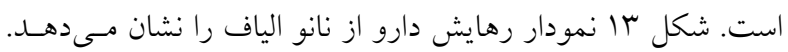
بهطوركلى رهايش ونكومايسين را با توجه به نمودار مىتوان به سـهـ

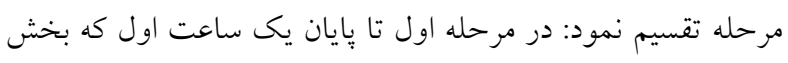
بيشتر ونكومايسين در اين مرحله رهايش شده است. در اين مرحله

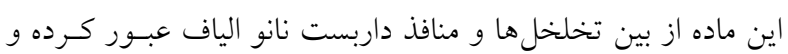

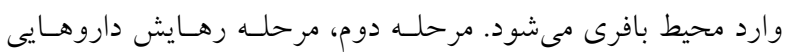

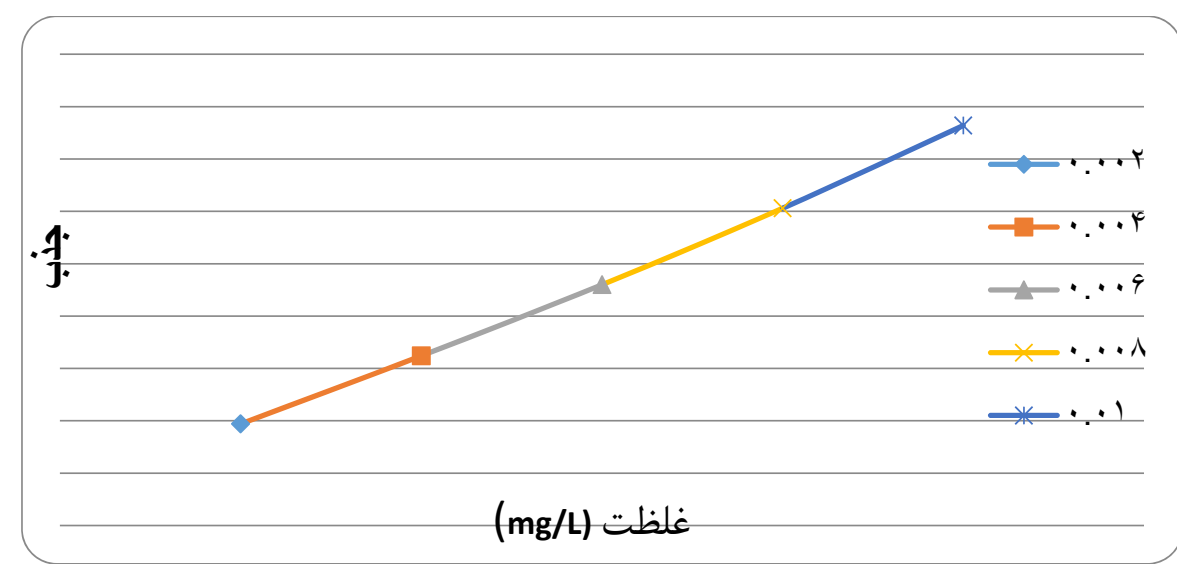

شكل r 1): نمودار كاليبراسيون ونكومايسين

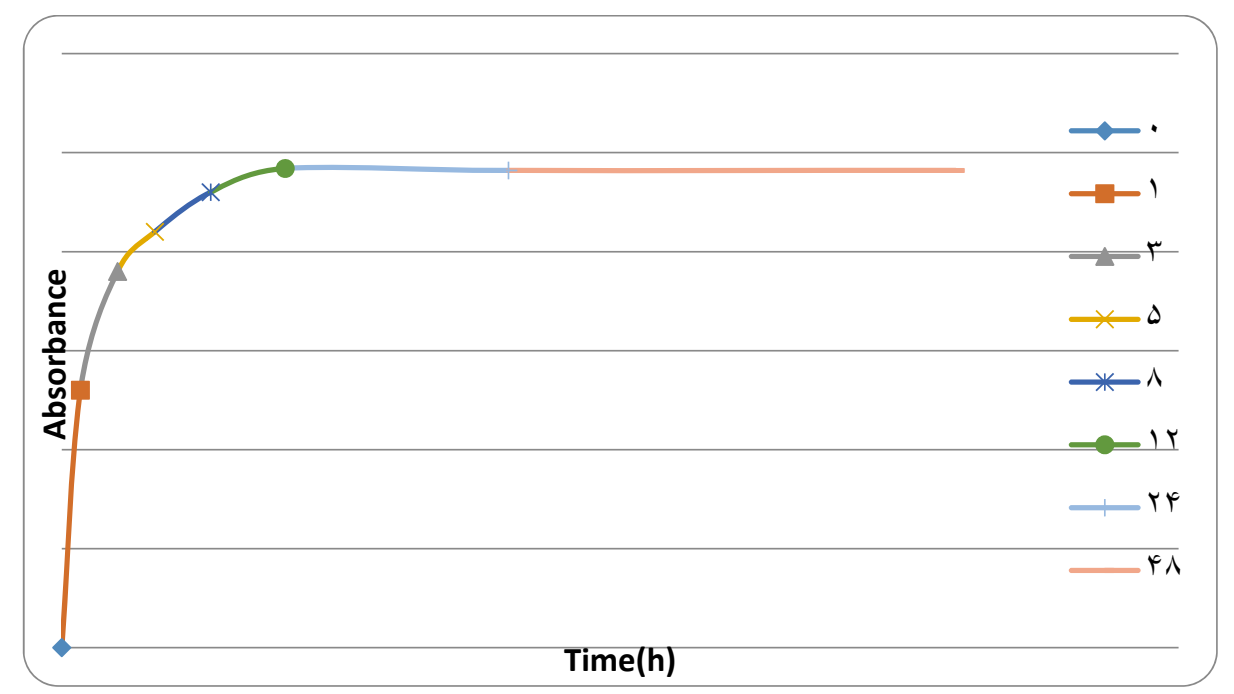

شكل با ا: نمودار رهايش ونكوماسين از داربست نانو الياف 
نانو اليـاف بِليمـرى كيتوسـان/ بلـى(اتسيلناكســايد) اسـتفاده نمـود.

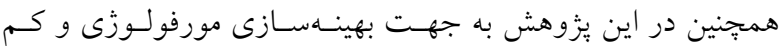
شدن قطر نانو الياف، افزايش ميزان تخلخل و يكدست بر شدن آنها از بلى كايرولاكتون استفادهشــه اسـت ـ از سـوى ديخــ، بـهمنظـور افزايش خاصيت ضد باكترى اين نـانو اليـاف عليـه عوامـل عفـونى

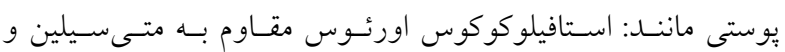
استريتوكوكوس بيوزنز ، آنتىبيوتيك ونكومايسين مى تواند بهعنـوان

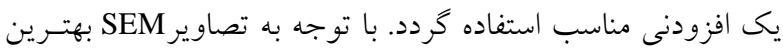
مورفولوزى با در نظر كرفتن بيشترين خصلت آنتى باكتريالى به نانو

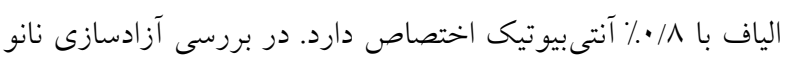

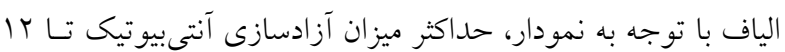

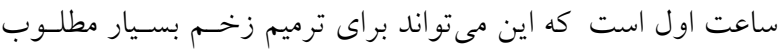

\section{References}

1. Zahedi P, Rezaeian I, Ranaei-Siadat SO, et al. A review on wound dressings with an emphasis on electrospun nanofibrous polymeric bandages. Polymers for Advanced Technologies. 2010; 21(2):77-95.

2. Ratner BD. Biomaterials science: an introduction to materials in medicine: Academic press; 2004.

3. Ramakrishna S, Fujihara K, Teo W, et al. An Introduction to Electrospinning and Nanofiber, World Scientific Publishing Co. Pte. Ltd, 2005.

4. Jayakumar R, Prabaharan M, Reis R, Mano J: Graft copolymerized chitosan-present status and applications. Carbohyd. Polym, . 2005; 62(2):142-158.

5. Ignatova M, Starbova K, Markova N, et al. Electrospun nano-fibre mats with antibacterial properties from quaternised chitosan and poly (vinyl alcohol). Carbohyd.
هدف اين كارتحقيقى، توليد يك نوع بوشـش زخسم مناسـب از

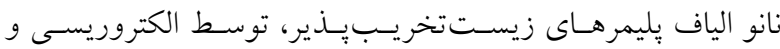
بررسى شرايط عملياتى جهت بهينه كردن ساختار نانو الياف حساوى ونكومايسين مىباشد. در اين يززوهش يارامترهاى عملياتى: ولتاز (در

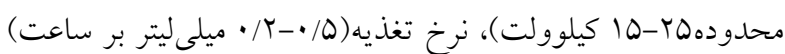

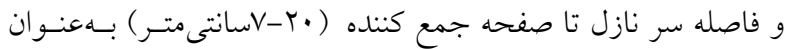
يارامترهاى فرايند الكتروريسى انتخاب شدند. بـس از انجـام فراينـــ الكتروريسى و تهيه تصاوير ميكروسكويى تستهاى آنتسىباكتريسالى لنى

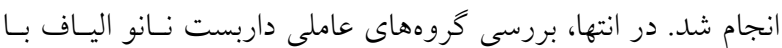

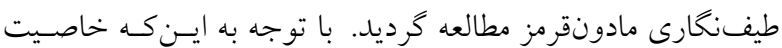
ضد باكترى و زيست تخريب بذيرى كيتوسان به اثبـات رسـيده، ايسن نتيجه حاصل مىشود كه مىتوان براى درمان زخــمهـاى سـطحى از

Res. 2006; 341(12): 2098-107.

6. Elzein T, Nasser-Eddine M, Delaite C, et al. FTIR study of polycaprolactone chain organization at interfaces. Journal of colloid and interface science 2004; 273(2):381-7.

7. Gavini E, Chetoni P, Cossu M, et al. PLGA microspheres for the ocular delivery of a peptide drug, vancomycin using emulsification/spray-drying as the preparation method: in vitro/in vivo studies. European journal of pharmaceutics and biopharmaceutics 2004; 57(2):207-12.

8.Fazli Y, Shariatinia Z. Controlled release of cefazolin sodium antibiotic drug from electrospun chitosanpolyethylene oxide nanofibrous. Mats Mater Sci and Eng C. $2017 ;$ 71: 641-52.

9. Sadri M, Arab Sorkhi S. Preparation and characterization of CS/PEO/cefazolin nanofibers with in vitro and in vivo testing, Nanomed Res J 2017; 2(2):100-110. 